\title{
Influence of physicochemical water quality on aquatic macrophyte diversity in seasonal wetlands
}

\author{
S. Rameshkumar ${ }^{1,2} \cdot$ Kalidoss Radhakrishnan $^{3} \cdot$ S. Aanand ${ }^{3} \cdot$ R. Rajaram ${ }^{2}$
}

Received: 1 June 2016 / Accepted: 27 December 2018 / Published online: 3 January 2019

(c) The Author(s) 2019

\begin{abstract}
The present study aims to assess the physicochemical parameters and distribution of aquatic macrophytes of seasonal wetlands flowing into the coast of Palk Bay, southeast coast of India. We tested the hypothesis whether there is any statistically significant difference in physicochemical parameters and macrophyte communities among study location. Water quality parameters such as temperature, $\mathrm{pH}$, salinity, TDS, DO, turbidity and electrical conductivity, and the aquatic macrophyte diversity were estimated in all three stations. One-way analysis of variance (ANOVA) and Pearson correlation were employed to assess the relationship between water quality parameters, and the water quality index (WQI) was computed to assess the status of water conditions. The ANOVA revealed that there is no statistically significant difference $(p>0.05)$ in water quality parameters among the three stations. The lowest $f$ value 0.180 was recorded for $\mathrm{pH}$ and highest of 2.478 for TDS. A total of 7 submerged macrophytes, namely Ceratophyllum demersum L., Egeria densa Planch., Lemna minor L., Marsilea quadrifolia L., Sagittaria guayanensis and Isoetes riparia; 6 rooted floating weeds, namely Potamogeton nodosus Poir., Nymphaea odorata Aiton., Nelumbo nucifera Gaertn., Myriophyllum spicatum L. and Hydrilla verticillata; 1 floating, namely Eichhornia crassipes Kunth; and 1 rooted macrophyte, namely Najas minor, were recorded in Tharavai wetland. A deplorable water quality condition was found in the selected study area, which was evidenced from WQI (>76\%). Of this, submerged aquatic vegetation is used as the water quality key indicator, and it exists where there is a better water quality condition. The EC, TDS and turbidity negatively influenced the aquatic macrophytes. Therefore, there is a need for some adaptation measure to maintain the water quality for more extended period for domestic use.
\end{abstract}

Keywords Seasonal wetland $\cdot$ Physicochemical parameters $\cdot$ Water quality index $\cdot$ Macrophytes $\cdot$ Wetland ecosystem

\section{Introduction}

Wetlands are essential element in biological diversity and ecosystem function. This utility performance varied by the hydrological and ecosystem functions (Banner and MacKenzie 2000). This is a most productive system which carried out critical regulatory functions of hydrological process within the watershed (Banner et al.

S. Rameshkumar

rameshkumarbotany@gmail.com

1 Department of Environmental Sciences, Madurai Kamaraj University, Madurai, Tamil Nadu 625 021, India

2 Present Address: Department of Marine Science, Bharathidasan University, Tiruchirapalli, Tamil Nadu 620 024, India

3 Fisheries College and Research Institute, Thoothukudi, Tamil Nadu 628 008, India
1988). In natural condition, wetlands provide essential habitat for many wildlife such as fish species, animals, birds, amphibians and mammals, plant species (macrophytes, plankton diversity) and focal ecosystem for many other (Hernandez and Mitsch 2007; Palit and Mukherjee 2012). Aquatic plants can act as measurable indicators of the ecological conditions of surface waters. Notably, the submerged species strongly dependent on water quality have proved to be vulnerable to changes in the aquatic environment (Robach et al. 1996; Dawson et al. 1999). The light transmission decreased by an increase in water turbidity, which leads to changes in community structure and reduction in vegetation diversity and depth (Middleboe and Markager 1997; Duarte et al. 1986; Chambers and Kalff 1985). Thus, submerged macrophytes are considered to be suitable eutrophication indicators and are sensitive to local environmental conditions (Dennison et al. 1993; Lacoul and Freedman 2006; Sondergaard 
et al. 2010). Aquatic vegetation can also influence the abiotic conditions (Flessa 1994; Moore et al. 1994; Barko et al. 1991) and influence wetland biota across multiple trophic levels (Norlin et al. 2005) by providing both habitat and food. The hydrodynamics of the ecosystem varied with soils, topography, climate, hydrology, water chemistry, vegetation and other factors including human disturbance. The fast development of industrial, urban and agricultural activities contributes to the significant alteration and destruction of wetland (Banner and MacKenzie 2000). Present day, the importance of wetlands has focused considerably due to rich potential production, untapped resources and productive nourishment resources for many other organisms (Williams 1990; Secmen and Leblebici 1996). However, the aquatic macrophytes also influence the water quality changes and being used as bio-indicator of pollution (Tripathi and Shukla 1991). The present study aims to investigate the status of the physiochemical parameters and its influences of aquatic macrophytes in seasonal wetland ecosystem in the southeast coast of India.

\section{Materials and methods}

\section{Description of the study area}

Tharavai wetland is one of the essential and largest freshwater seasonal wetland ecosystems in Ramanathapuram district of Tamil Nadu, southeast coast of India (Fig. 1), which receives water mainly from precipitation. Water is available throughout the year and is mainly used for bathing, washing clothes, sheep grazing, irrigation and fishing by local folks. This wetland originates from Regunathapuram village near to Ramanathapuram town, and it has a length of $35-40 \mathrm{~km}$ and breadth of 100-200 m up to Pirappanvalasai village. Then it flows in the small channel (30-40 m breadth) and finally ends in Palk Bay coast. The total area of wetland ecosystem is $2425.6 \mathrm{ha}(245.5 \mathrm{sq} . \mathrm{km})$ - a total stretch of $15 \mathrm{~km}$ of Tharavai wetland located along the coastal villages like Thamaraikulam, Ammapattinam, Pudumadam, Nariyurani, Katukkavalasai, Notchiyurani and Manankudi. Of this, three sites were selected for sampling, namely Thamaraikulam, Pudumadam and Manankudi.

Station 1 is the Thamaraikulam site located $2.5 \mathrm{~km}$ away from Pudumadam village. The breadth is $100-200 \mathrm{~m}$, and

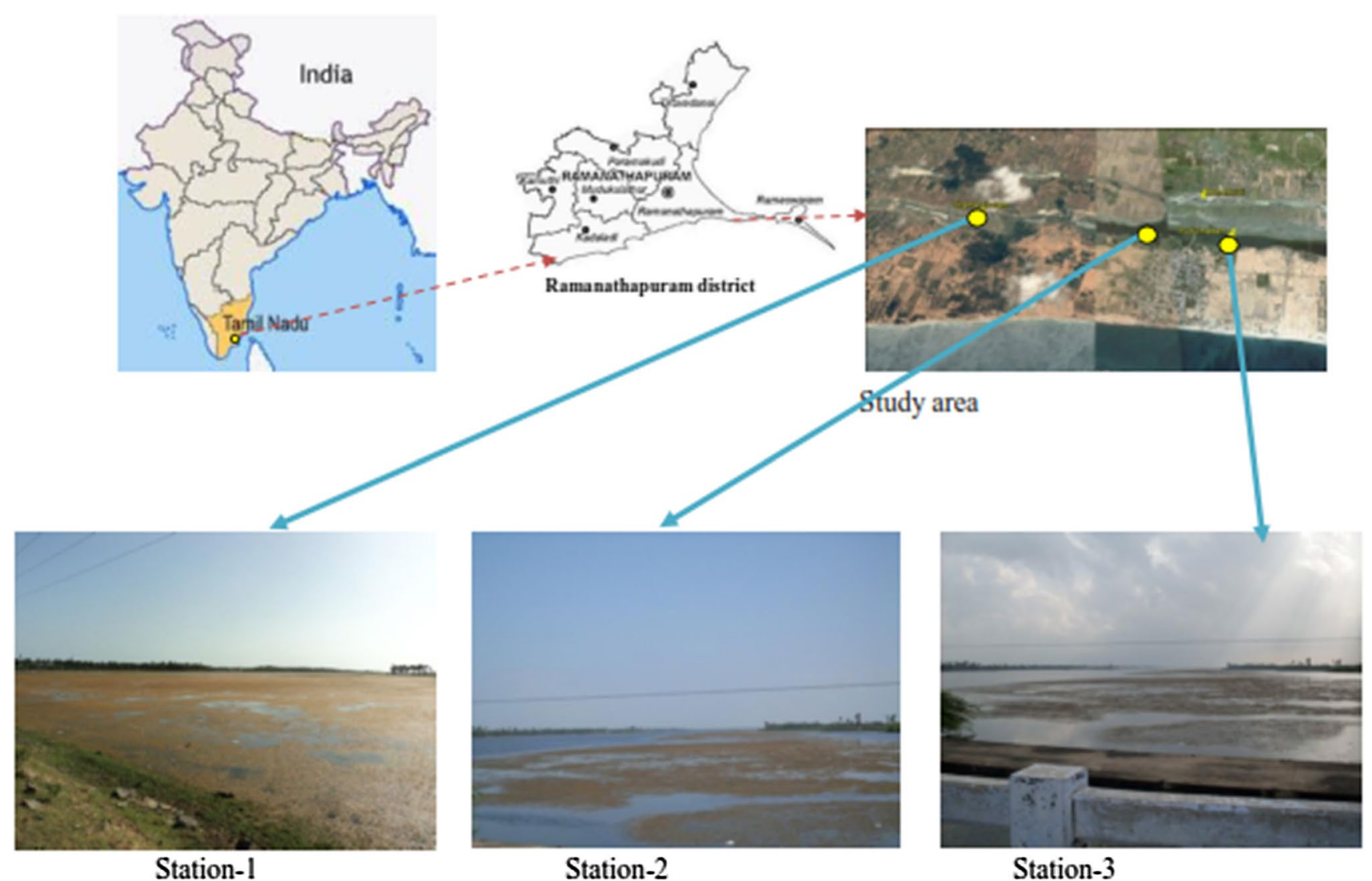

Fig. 1 Sampling stations in Tharavai wetland, Ramanathapuram district of India 
the depth is $5-10$ feet. The northern part of this station is occupied by agricultural lands mainly paddy field, cereals and coconut cultivation. Station 2 is Manankudi village is situated in the eastern side of Pudumadam village and ending in Pirappanvalasai village. The length of this station is $4 \mathrm{~km}$ long, and breadth is $100-200 \mathrm{~m}$. The depth varies between 5 and 10 feet. However, the northern part of the Manankudi is also covered by agricultural lands, mostly paddy fields. Station 3 is situated in Pudumadam: The breadth varies from 100 to $200 \mathrm{~m}$, and the depth varies between 5 and 10 feet. This station is situated in the southern part of wetland, and the agricultural lands cover the northern part. The bank of this wetland is maximum covered by Acacia sp. and Cyperus sp., and some other varieties of grasses (Poaceae family members) were also present.

\section{Physicochemical parameters analysis}

To estimate the physicochemical water quality, the samples were collected from the selected study area (north and south direction) fortnightly from February 2010 to January 2011. Temperature, $\mathrm{pH}$ and salinity were observed in situ using a mercury-in-glass thermometer, portable $\mathrm{pH}$ meter (Eutech, Japan) and refractometer (ATAGO, Japan), respectively. The dissolved oxygen (DO) was determined by using Winkler's method (APHA 1998). Turbidity (NTU) and conductivity were measured using a TN-100 turbid meter by Eutech Instruments, Singapore, and conductivity meter, model 1601, respectively. Total dissolved solid was described using the method by Goel and Trivedy (1987).

\section{Identification of wetland flora}

The aquatic plants were collected from the study area; it was preserved by using formalin in polythene bags. All the aquatic hydrophytes were identified using standard protocols published in books and literature (Nair and Henry 1983; Henry et al. 1987, 1989; Matthew 1991; Saini et al. 2010).

\section{Statistical analysis}

The statistical tools such as ANOVA, correlation and water quality index (WQI) of physicochemical parameters were used. Pearson correlation $(r)$ test was carried out to identify the association between pairs of variables for sampling stations and the number of species. The water quality index is a fundamental mathematical tool for calculating a single value from multiple test results. The results of an index represent the level of water quality in a given water basin such as lake, river, stream and ponds too (Akkaraboyina and Raju 2012). WQI attempts to provide a mechanism for presenting a cumulatively derived, numerical expression defining a certain level of water quality (Miller et al. 1986). In this study, seven parameters were chosen to calculate the water quality index, using the standards of drinking water quality recommended by BIS (1993) and ICMR (1975).

Water quality index of wetland water is calculated by adopting Chaterjee and Razuddin (2002) method, and the formula is given below.

$\mathrm{WQI}=\sum_{n=1}^{n} q_{n} w_{n} / \sum_{n=1}^{n} w_{n}$

where $\left.q_{n}=100\left[V_{n}-\mathrm{Vio}\right] /\left(S_{n}-\mathrm{V} 10\right)\right], q_{n}$ quality rating for the $i$ th water quality parameter; $V_{n}$ estimated value of the $i$ th parameter at a given sampling station; $S_{n}$ standard permissible value of $i$ th parameter; Vio ideal value of $i$ th parameter in pure water $(\mathrm{pH} 7, \mathrm{DO}=14 \mathrm{mg} / \mathrm{l}$ and for other parameter $=0$ ); $W_{n}$ unit weight for $i$ th parameter; $S_{n}$ standard value for $i$ th parameter; $K$ constant for proportionality.

\section{Results and discussion}

Physicochemical parameters are considered as one of the most important factors that are capable of influencing the aquatic environment and have shown wide temporal and spatial differences. The statistical variations in the water quality parameters for the seasonal wetlands are presented in Table 1. Temperature is one of the controlling factors, which alter the functions of the aquatic ecosystem, and it influences the growth and distribution of flora and fauna (Dwivedi and Pandey 2002; Singh and Mathur 2005; Jalal and Sanalkumar 2012; Tank and Chippa 2013). Temperature has been determined using the pattern of distribution of macrophytes, thereby influencing the productivity and species composition, and this is varied with depth, season and geographical location. The temperatures were consistent between the wetland to wetland; it was ranged from $30.78 \pm 0.45$ to $31.57 \pm 0.32{ }^{\circ} \mathrm{C}$ with this minimum and maximum being recorded in station 2 and station 1, respectively. It is not easy to discriminate the difference between the effects of environmental variables on the distribution of aquatic macrophytes. Human effect on the environment and natural activities switches the structure of aquatic macrophytes. Eutrophication affects the concentration of distribution, diversity and density and productivity of macrophytes. The $\mathrm{pH}$, which regulates the acidic or basic characteristics, is a vital property of any aquatic ecosystem since all the biochemical functions and retention of physicochemical attributes of the water are greatly depending on $\mathrm{pH}$ of the surrounding environments (Jalal and Sanalkumar 2013). Most of the similar studies recommended that water samples are slightly alkaline due to the presence of carbonates and bicarbonates (Tank and Chippa 2013; Gopalkrushna 2011;

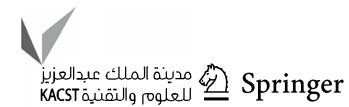


Table 1 Physicochemical characteristics of Tharavai wetland at selected sampling stations

\begin{tabular}{|c|c|c|c|c|c|c|c|c|c|c|c|}
\hline \multirow[t]{2}{*}{ Parameters } & \multicolumn{3}{|c|}{ Station 1} & \multicolumn{3}{|c|}{ Station 2} & \multicolumn{3}{|c|}{ Station 3} & \multirow[t]{2}{*}{$F$ value } & \multirow[t]{2}{*}{$P$ value } \\
\hline & Min & Max & $(\mathrm{Mean} \pm \mathrm{SD})$ & Min & Max & $($ Mean $\pm \mathrm{SD})$ & Min & Max & $($ Mean $\pm S D)$ & & \\
\hline Temperature $\left({ }^{\circ} \mathrm{C}\right)$ & 30.5 & 32.7 & $31.57 \pm 0.32^{\mathrm{a}}$ & 29.5 & 32.5 & $30.78 \pm 0.45^{\mathrm{b}}$ & 30.0 & 32.0 & $31.00 \pm 0.34^{\mathrm{a}}$ & 1.106 & 0.041 \\
\hline $\mathrm{pH}$ & 7.0 & 7.7 & $7.32 \pm 0.11^{\mathrm{a}}$ & 7.2 & 7.6 & $7.43 \pm 0.07^{\mathrm{a}}$ & 7.1 & 7.6 & $7.33 \pm 0.09^{\mathrm{a}}$ & 0.180 & 0.065 \\
\hline Salinity (ppt) & 0.7 & 1.6 & $1.13 \pm 0.15^{\mathrm{a}}$ & 0.8 & 0.9 & $0.82 \pm 0.02^{\mathrm{ab}}$ & 0.8 & 1.0 & $0.88 \pm 0.03^{\mathrm{ab}}$ & 1.181 & 0.074 \\
\hline Conductivity $(\mathrm{ms} / \mathrm{cm})$ & 355.0 & 586.0 & $435.33 \pm 43.88^{\mathrm{a}}$ & 348.0 & 372 & $355.75 \pm 4.4^{\mathrm{ab}}$ & 350.0 & 378 & $361.75 \pm 4.15^{\mathrm{b}}$ & 1.129 & 0.046 \\
\hline TDS (mg/l) & 249.0 & 320.0 & $275.42 \pm 12.77^{\mathrm{a}}$ & 214.0 & 254.5.0 & $230 \pm 7.56^{\mathrm{ab}}$ & 223.0 & 250.0 & $238.17 \pm 4.53^{\mathrm{ab}}$ & 1.004 & 0.056 \\
\hline DO (mg/l) & 7.8 & 8.4 & $8.05 \pm 0.1^{\mathrm{a}}$ & 7.7 & 8.4 & $7.97 \pm 0.1^{\mathrm{a}}$ & 7.4 & 8.1 & $7.88 \pm 0.1^{\mathrm{a}}$ & 2.478 & 0.092 \\
\hline Turbidity (NTU) & 3.7 & 6.6 & $5.38 \pm 0.53^{\mathrm{a}}$ & 3.7 & 6.0 & $4.57 \pm 0.4^{b}$ & 3.9 & 6.0 & $4.63 \pm 0.37^{b}$ & 0.370 & 0.086 \\
\hline
\end{tabular}

Different letters in a row have statistical significance at 0.05 level

Verma et al. 2012). This can be toxic when it is more than the desirable limit and can influence the ammonia, hydrogen sulfide and heavy metals (Klontz 1993). The higher level of $\mathrm{pH}$ can affect the aquatic life at a certain level; however, an optimum level of 7-8.5 was recommended by BIS (2003). In the present study, the $\mathrm{pH}$ was ranged from $7.32 \pm 0.11$ to $7.43 \pm 0.07$ with lowest and highest being recorded in station 1 and station 2, respectively. This finding was supported by Bala and Mukherjee (2010) who observed the pH 5.34-8.67 in Nadia wetlands of West Bengal. The minimum concentration of salinity $0.82 \pm 0.02 \%$ was recorded in station 2 , and the maximum of $1.13 \pm 0.15 \%$ o was recorded in station 1. The salinity is the main physical parameter that can be attributed to the biological diversity, which acts as a limiting factor and influences the distribution of aquatic organisms (Kouwenberg 1994; Neelam and Nair 1997; Chandramohan and Sreenivas 1998; Balasubramanian and Kannan 2005; Sridhar et al. 2006). Electrical conductivity is the measure of the ability of an aqueous solution to transmit an electric current in the aquatic environments (Lodh et al. 2014). It was found to be lowest of $355.75 \pm 4.4 \mathrm{~ms} / \mathrm{cm}$ in station 2 and highest of $435.33 \pm 43.88 \mathrm{~ms} / \mathrm{cm}$ in station 1 . Bala and Mukherjee (2010) supported this study results. Total dissolved solids (TDS) are the materials dissolved in water like bicarbonate, sulfate, phosphate, nitrate, calcium, magnesium, sodium and organic ions. In the present study, TDS ranged from $230 \pm 7.56$ to $275.42 \pm 12.77 \mathrm{~ms} / \mathrm{cm}$ with the minimum in station 2 and maximum recorded in station 1, which is influenced mainly by the urbanization, fertilization runoff (agricultural) and domestic effluents. Present findings correlated with the earlier reports (Bala and Mukherjee 2010). Dissolve oxygen (DO) regulates that health of the ecosystems refers to the volume of oxygen present in the water body. It is an important water quality parameter to maintain because of its significant biological and physicochemical property of surrounding water. Oxygen enters into the water by aerial diffusion and as a photosynthetic by-product of aquatic plants (Kotadiya Nikesh and Acharya 2014). The DO depends upon the temperature, salinity and pressure of the water. The DO level indicates the degree of pollution in the water bodies (Gopalkrushna 2011). A minimum DO of $5 \mathrm{mg} / \mathrm{l}$ is recommended (BIS/ICMR). In the present study, a minimum of $7.88 \pm 0.1 \mathrm{mg} / \mathrm{l}$ was recorded in station 3, whereas a maximum of $8.05 \pm 0.1 \mathrm{mg} / \mathrm{l}$ was recorded at station 1 . However, in the present study, the dissolved oxygen was found to be more than the required limit and has negative influences toward these wetland ecosystems. Turbidity is the expression of optical property by

Table 2 Pearson correlation coefficients matrix between the physicochemical parameters of study area

\begin{tabular}{|c|c|c|c|c|c|c|c|c|}
\hline Parameters & Temperature $\left({ }^{\circ} \mathrm{C}\right)$ & $\mathrm{pH}$ & Salinity (ppt) & DO (mg/l) & $\begin{array}{l}\text { Conductiv- } \\
\text { ity }(\mathrm{ms} / \mathrm{cm})\end{array}$ & TDS (mg/l) & Turbidity (NTU) & Species nos. \\
\hline Temperature $\left({ }^{\circ} \mathrm{C}\right)$ & 1 & & & & & & & \\
\hline $\mathrm{pH}$ & -0.325 & 1 & & & & & & \\
\hline Salinity (ppt) & 0.628 & -0.64 & 1 & & & & & \\
\hline DO (mg/l) & -0.04 & -0.139 & 0.433 & 1 & & & & \\
\hline Conductivity $(\mathrm{ms} / \mathrm{cm})$ & 0.58 & -0.575 & $.987 * *$ & 0.526 & 1 & & & \\
\hline TDS (mg/l) & 0.638 & -0.654 & $.987 * *$ & 0.513 & $.989 * *$ & 1 & & \\
\hline Turbidity (NTU) & 0.475 & -0.574 & $.975 * *$ & 0.474 & $.984 * *$ & $.956 * *$ & 1 & \\
\hline Species nos. & -0.482 & 0.211 & -0.803 & -0.515 & $-.877 *$ & $-.824^{*}$ & $-.858 *$ & 1 \\
\hline
\end{tabular}

**Correlation is significant at the 0.01 level (two-tailed)

*Correlation is significant at the 0.05 level (two-tailed) 
which light is scattered by the colloidal particles present in the water. Phytoplankton, microscopic organisms, clay and other organic matter make a lake turbid (Das and Shrivastva 2003). In the present study, the minimum concentration of $4.57 \pm 0.4 \mathrm{NTU}$ was recorded in station 2 and the maximum of $5.38 \pm 0.53 \mathrm{NTU}$ was recorded in station 1, which was supported by Bala and Mukherjee (2010).

The correlation matrix of mean water quality parameters was computed to assess the relationship between the stations. The salinity was strongly positively correlated with electrical conductivity $(r=0.987)$, total dissolved solids $(r=0.987)$ and turbidity $(r=0.975)$ at $p<0.01$ level. The conductivity was strongly positively correlated with TDS $(r=0.989)$ and turbidity $(r=0.984)$ with a statistical significance level of 0.01 , whereas electrical conductivity was negatively correlated with the distribution of species $(r=-0.877)$ at $p<0.05$ level. Total dissolved solids were strongly correlated with turbidity $(r=0.956)$ at $p<0.01$ level and negatively correlated with the distribution of species numbers $(r=-0.824)$ with a statistical significance level of 0.05 level. Turbidity was also negatively correlated with the number of species $(r=-0.858)$ with statistically significant at the 0.05 level (Table 2). One-way analysis of variance (ANOVA) was conducted to explore the relationship of water quality in the different study areas. The statistically significant difference at $a p<0.05$ level was noted in temperature, conductivity and total dissolved solids for the three stations, whereas no significant difference at the $p>0.05$ level was observed for the parameters such as $\mathrm{pH}$, salinity, dissolved solids and turbidity at all stations (Table 1).

Our results highlight that there is considerable variability in the aquatic habitat of seasonal wetlands. Physicochemical factors that alter the habitat structures differences among wetland classes are recognized, as are biogeographic factors significant that structuring wetland communities on broad spatial scales (Brazner and Beals 1997; Lougheed et al. 2001). The strong relations between common plant species and water properties potentially impact the changes in aquatic ecosystems (Naiman et al. 1993), and we made comparisons only among the water parameters and aquatic vegetations of the seasonal wetlands. In the present study, a total of 15 aquatic plant species were recorded; these species belong to 7 classes, 9 orders and 12 families. A total of 7 submerged macrophytes, namely Ceratophyllum demersum L., Egeria densa Planch., Lemna minor L., Marsilea quadrifolia L.,

Table 3 List of aquatic plants species that were recorded in the seasonal wetlands

\begin{tabular}{|c|c|c|c|c|c|c|c|c|}
\hline S. no & Scientific name & Family & Common name & IUCN red list & Type & St-1 & St-2 & St-3 \\
\hline 1 & $\begin{array}{l}\text { Ceratophyllum demer- } \\
\text { sum } \mathrm{L} \text {. }\end{array}$ & Ceratophyllaceae & Rigid hornwort & Least concern (stable) & Submerged & $\checkmark$ & $\checkmark$ & $\checkmark$ \\
\hline 2 & Egeria densa Planch. & Hydrocharitaceae & Egeria & - & Submerged & $\checkmark$ & $\checkmark$ & $\checkmark$ \\
\hline 3 & Lemna minor $\mathrm{L}$. & Araceae & Common duckweed & $\begin{array}{l}\text { Least concern (un } \\
\text { known) }\end{array}$ & Submerged & $x$ & $\checkmark$ & $x$ \\
\hline 4 & Marsilea quadrifolia $\mathrm{L}$. & Marsileaceae & Water shamrock & $\begin{array}{l}\text { Least concern } \\
\text { (unknown) }\end{array}$ & Submerged & $x$ & $\checkmark$ & $x$ \\
\hline 5 & $\begin{array}{l}\text { Potamogeton nodosus } \\
\text { Poir. }\end{array}$ & Potamogetonaceae & Loddon pondweed & $\begin{array}{l}\text { Least concern (un } \\
\text { known) }\end{array}$ & Rooted and floating & $x$ & $\checkmark$ & $x$ \\
\hline 6 & $\begin{array}{l}\text { Nymphaea nouchali } \\
\text { Burm. f }\end{array}$ & Nymphaeaceae & Red or blue water lily & $\begin{array}{l}\text { Least concern (un } \\
\text { known) }\end{array}$ & Submerged & $x$ & $x$ & $\checkmark$ \\
\hline 7 & $\begin{array}{l}\text { Nymphaea odorata } \\
\text { Aiton. }\end{array}$ & Nymphaeaceae & Indian lotus & - & Rooted and floating & $x$ & $x$ & $\checkmark$ \\
\hline 8 & $\begin{array}{l}\text { Nelumbo nucifera } \\
\text { Gaertn. }\end{array}$ & Nelumbonaceae & White water lily & - & Rooted and floating & $x$ & $x$ & $\checkmark$ \\
\hline 9 & $\begin{array}{l}\text { Myriophyllum spicatum } \\
\text { L. }\end{array}$ & Haloragidaceae & Spiked watermilfoil & $\begin{array}{l}\text { Least concern (un } \\
\text { known) }\end{array}$ & Rooted and floating & $\checkmark$ & $\checkmark$ & $\checkmark$ \\
\hline 10 & Hydrilla verticillata & Hydrocharitaceae & Indian star grass & $\begin{array}{l}\text { Least concern } \\
\text { (unknown) }\end{array}$ & Rooted and floating & $\checkmark$ & $\checkmark$ & $\checkmark$ \\
\hline 11 & Chara globularis & Characeae & Muskgrass or skunweed & - & Rooted and floating & $\checkmark$ & $\checkmark$ & $\checkmark$ \\
\hline 12 & Sagittaria guayanensis & Alismataceae & Arrowhead & - & Submerged & $x$ & $\checkmark$ & $\checkmark$ \\
\hline 13 & Isoetes riparia & Isoetaceae & Quillwort & - & Submerged & $\checkmark$ & $x$ & $\checkmark$ \\
\hline 14 & $\begin{array}{l}\text { Eichhornia crassipes } \\
\text { Kunth }\end{array}$ & Ponteteriaceae & Water hyacinth & - & Floating & $x$ & $x$ & $\checkmark$ \\
\hline 15 & Najas minor & Hydrocharitaceae & Slender naiad & $\begin{array}{l}\text { Least concern (un } \\
\text { known) }\end{array}$ & Rooted & $\checkmark$ & $\checkmark$ & $\checkmark$ \\
\hline \multicolumn{6}{|c|}{ Total number of species in each stations } & 7 & 10 & 12 \\
\hline
\end{tabular}


Table 4 Water quality index (WQI) and status of water quality status

\begin{tabular}{ll}
\hline Water quality index & Water quality status \\
\hline $0-25$ & Excellent water quality \\
$26-50$ & Good water quality \\
$51-75$ & Poor water quality \\
$76-100$ & Very poor water quality \\
$>100$ & Unsuitable for drinking \\
\hline
\end{tabular}

Sagittaria guayanensis and Isoetes riparia; 6 rooted floating weeds, namely Potamogeton nodosus Poir., Nymphaea odorata Aiton., Nelumbo nucifera Gaertn., Myriophyllum spicatum $\mathrm{L}$. and Hydrilla verticillata; 1 floating, namely Eichhornia crassipes Kunth; and 1 rooted macrophyte, namely Najas minor, were recorded in Tharavai wetland (Table 3). Adhishwar and Choudhary (2013) observed 137 macrophytes belong to 50 families in Gogabil lake wetland, Bihar, India. The submerged and free-floating hydrophytes have a higher capacity to remove large concentrations of nutrients (Sooknah and Wilkie 2004; Greenway 1997). Water hyacinth can be used to remove the higher amount of nitrogen concentration per square meter of growing area and is the fastest growing plant in the wastewater (Rakocy and Allison 1981). Free-floating macrophyte of Eichhornia crassipes Kunth was present in Thamaraikulam station. It has positive and negative impacts on the ecosystem and water quality. It affects the diminished flow of water, degrades the water quality by air water interface and greatly reduces the dissolved oxygen concentration in the water bodies (Penfound and Earle 1948). This also reduces the biological diversity, eliminating the native submerged species by obstructive sunlight and eliminating the underwater species like fishes (Gowanloch 1944). Water quality index is used to evaluate the status of characteristics of water table, the rage of the quality index and their status presented in Table 4. Water parameters regulates the distribution of aquatic plants; the temperature ranged from 30.5 to $32.7^{\circ} \mathrm{C} ; \mathrm{pH} 7.0-7.7$; salinity $0.7-1.6 \mathrm{ppt}$; conductivity $355-586 \mathrm{~ms} / \mathrm{cm}$; TDS $249-320 \mathrm{~ms} / \mathrm{cm}$; DO 7.8-8.4 mg/l; and turbidity 3.7-6.6 NTU with minimum of 7 species were recorded at station 1 due to the very poor water quality status and this evidenced from the results of WQI 86.25 (Table 5). This may be attributed due to increased suspended solids and algal blooms (Ruttner 1953; Wetzel 1966); this is conformed from the results of turbidity which was found to be higher in station 1 than that of other stations. This finding was also supported by Dennison et al. (1993) who studied the water quality by using aquatic submerged weeds in the Chesapeake Bay. Ten species were recorded in station 2, with the temperature ranged from 29.5 to $32.5{ }^{\circ} \mathrm{C} ; \mathrm{pH}$ 7.2-7.6; salinity $0.8-0.9 \mathrm{ppt}$; conductivity $348-372 \mathrm{~ms} /$

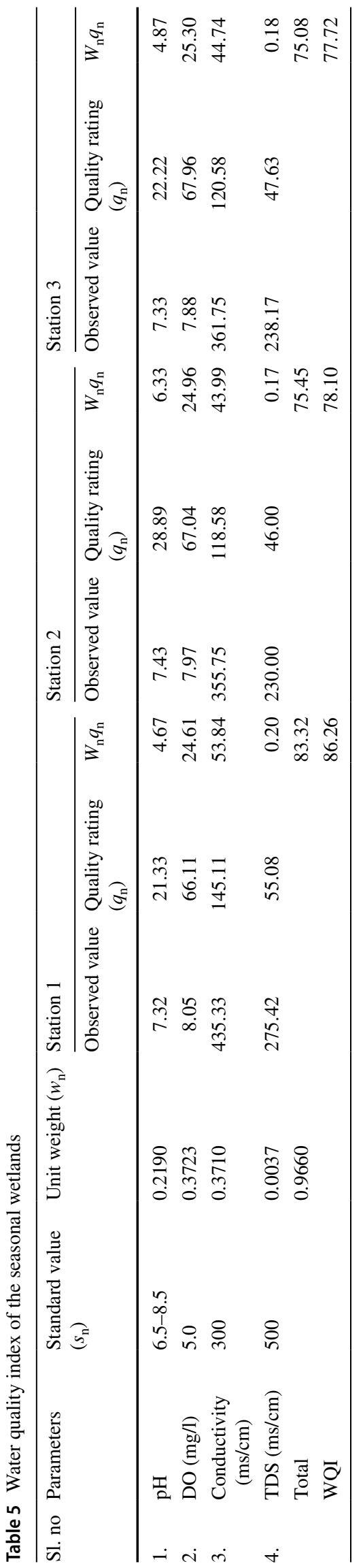


cm; TDS 214-254.5 ms/cm; DO 7.7-8.4 mg/l; and turbidity 3.7-6 NTU. However, 12 plant species were observed in station 3 due to irregular conditions with temperature ranged from 30 to $32{ }^{\circ} \mathrm{C}$; $\mathrm{pH} 7.1-7.6$; salinity $0.8-1.0$ ppt; conductivity $350-378$ (ms/cm); TDS $223-250$ (ms/ $\mathrm{cm}$ ); DO 7.4-8.1 mg/l; and turbidity 3.9-6.0 NTU. The estimated WQI was around 78.10 and 77.72 for stations 2 and 3, respectively (Table 5), which means it has very poor water quality. This finding was conformed by other observation of Thakor et al. (2011) Jena et al. (2013) and Korgaonkar et al. (2014). Besides, WQI variation has been attained due to the presence of additional submerged vegetation which means it has 5 submerged aquatic vegetation out of 7 submerged vegetation in stations 2 and 3. Dennison et al. (1993) reported the submerged aquatic vegetation as an indicator of water clarity and nutrient level of the water.

\section{Conclusion}

The water quality characteristics directly affect the aquatic macrovegetation, which was evidenced from the water quality index of the wetland. Also, the status of water quality varied due to usage and topography. Moreover, this study concludes that submerged aquatic vegetation is an indicator of the water quality parameter, despite the needed to take some adaptation measure to maintain the water quality for more extended domestic use.

Open Access This article is distributed under the terms of the Creative Commons Attribution 4.0 International License (http://creativeco mmons.org/licenses/by/4.0/), which permits unrestricted use, distribution, and reproduction in any medium, provided you give appropriate credit to the original author(s) and the source, provide a link to the Creative Commons license, and indicate if changes were made.

\section{References}

Adhishwar AK, Choudhary SK (2013) Diversity of macrophytic species of gogabil lake wetland in Katihar, Bihar, India. Ecol Environ Conserv 19(4):1165-1172

Akkaraboyina MK, Raju BSN (2012) A Comparative study of water quality indices of river Godavari. Int J Eng Res Dev 2(3):29-34

APHA (1998) Standard methods for the examination of water and wastewater, 20th edn. American Public Health Association, Washington, DC

Bala G, Mukherjee A (2010) Water quality index of some wetland in Nadia district, West Bengal, India. Int J Lake Rivers 4(1):21-26

Balasubramanian R, Kannan L (2005) Physico-chemical characteristics of the coral reef environs of the Gulf of Mannar biosphere reserve, India. Int J Ecol Environ Sci 31:265-271
Banner A, MacKenzie W (2000) The ecology of wetland ecosystem. 45 extension note. Ministry of Forest Research Program, Victoria, BC

Banner A, Hebda RJ, Oswald ET, Pojar J, Trowbridge R (1988) Wetlands of Pacific Canada. In: National Wetlands Working Group, Wetlands of Canada (eds) Ecological land classification series no 24, Environment Canada, Ottawa, pp 306-341

Barko JW, Gunnison D, Carpenter SR (1991) Sediment interactions with submersed macrophyte growth and community dynamics. Aquat Bot 41:41-65

BIS (1993) Standards of water for drinking and other purposes. Bureau of Indian Standards, New Delhi

BIS (2003) Indian Standard drinking water-specification. Manak Bhavan, New Delhi

Brazner JC, Beals EW (1997) Patterns in fish assemblages from coastal wetland and beach habitats in Green Bay, Lake Michigan: a multivariate analysis of abiotic and biotic forcing factors. Can J Fish Aquat Sci 54(8):1743-1761

Chambers PA, Kalff J (1985) Depth distribution and biomass of submerged aquatic macrophyte communities in relation to Secchi disc. Can J Fish Aquat Sci 42:701-709

Chandramohan P, Sreenivas N (1998) Diel variations in zooplankton population in mangrove ecosystem at Gaderu canal, south-east coast of India. Indian J Mar Sci 27:486-488

Chaterjee C, Razuddin M (2002) Determination of water quality index (W.Q.I.) of a degraded river in Asanil industrial area, Ranigunj, Burdwan, West Bengal. Nat Environ Pollut Technol 1(2):181-189

Das AK, Shrivastva NP (2003) Ecology of Sarny Reservoir (M.P.) in the context of fisheries. Pollut Res 22(4):533-539

Dawson FH, Newman JR, Gravelle MJ, Rouen KJ, Henville P (1999) Assessment of the tropic status of rivers using macrophytes. Evolution of the Mean Tropic Rank. Research and development. Technical report E39, Environment Agency, Bristol

Dennison WC, Orth RJ, Moore KA, Stevenson JC, Carter V, Kollar S, Bergstrom PW, Batiuk RA (1993) Assessing water-quality with submersed aquatic vegetation. Bioscience 43:86-94

Duarte CM, Kalff J, Peters H (1986) Patterns in biomass and cover of aquatic macrophytes in lakes. Can J Fish Aquat Sci 43:1900-1908

Dwivedi BK, Pandey GC (2002) Physico-chemical factors and algal diversity of two ponds Gurijakund and Maqubara pond Faizabad. Pollut Res 21:361-370

Flessa H (1994) Plant-induced changes in the redox potential of the rhizospheres of the submerged vascular macrophytes Myriophyllum verticillatum $\mathrm{L}$. and Ranunculus circinatus $\mathrm{L}$. Aquat Bot 47:119-129

Goel PK, Trivedy RK (1987) Chemical and biological methods for water pollution studies. Environmental Publications, Karad, pp $1-34$

Gopalkrushna MH (2011) Determination of physico-chemical parameters of surface water samples in and around Akot city. Int J Res Chem Environ 1(2):183-187

Gowanloch JN (1944) The economic status of water hyacinth in Louisiana. La Conserv 2:3-8

Greenway M (1997) Nutrient content of wetland plants in constructed wetland receiving municipal effluent in tropical Australia. Water Sci Technol 35:135-142

Henry AN, Kumari GR, Chitra V (1987) Flora of Tamil Nadu, India, vol 2. Series I: analysis. Botanical Survey of India, Coimbatore

Henry AN, Chitra V, Balakrishnan NP (1989) Flora of Tamil Nadu, India, vol 3. Series II: analysis. Botanical Survey of India, Coimbatore

Hernandez ME, Mitsch WJ (2007) De-nitrification in created riverine wetlands: influence of hydrology and season. Ecol Eng 30:78-88

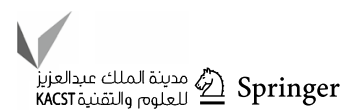


ICMR (1975) Manual of standards of quality for drinking water supplies. Indian Council of Medical Research. Special report no. 44: 27

Jalal FN, Sanalkumar MG (2012) Hydrology and water quality assessment of Achencovil river in relation to pilgrimage season. Int $\mathbf{J}$ Sci Res Publ 2(12):1-5

Jalal FN, Sanalkumar MG (2013) Water quality assessment of Pampa river in relation to pilgrimage season. Int $\mathrm{J}$ Res Chem Environ 3(1):341-347

Jena V, Dixit S, Gupta S (2013) Assessment of water quality index of industrial area surface water samples. Int $\mathbf{J}$ Chem Res 5(1):278-283

Klontz GW (1993) Environmental requirements and environmental diseases of salmonids. In: Stoskopf MK (ed) Fish medicine. W. B. Saunders Company, Philadelphia, pp 333-342

Korgaonkar DS, Bharamal DL, Koli YJ (2014) Determination of water quality index in Annapurna river in Devgad Taluka, district Sindhudurg, Maharashtra. Int Q J BioLife Sci 2(4):1268-1273

Kotadiya Nikesh G, Acharya CA (2014) An assessment of lake water quality index of Manipu lake of district Ahmedabad. Gujarat. Int J Sci Res 3(4):448-450

Kouwenberg JHM (1994) Copepod distribution in relation to seasonal hydrographic and spatial structure in the north-western Mediterranean (Gulf du Lion). Estuar Coast Shelf Sci 38:69-90

Lacoul P, Freedman B (2006) Environmental influences on aquatic plants in freshwater ecosystems. Environ Rev 14:89-136

Lodh R, Paul R, Karmakar B, Das MK (2014) Physico chemical studies of water quality with special reference to ancient lakes Udaipur city, Tripura, India. Int J Sci Res Publ 4(6):1-9

Lougheed VL, Crosbie B, Chow-Fraser P (2001) Primary determinants of macrophyte community structure in 62 marshes across the Great Lakes basin: latitude, land use, and water quality effects. Can J Fish Aquat Sci 58(8):1603-1612

Matthew KM (1991) An excursion Flora of Central Tamil Nadu. Rapinat Herbarium, Thiruchirappalli, p 682

Middleboe AL, Markager S (1997) Depth limits and minimum light requirements of freshwater macrophytes. Freshw Biol 37:553-568

Miller WW, Joung HM, Mahannah CN, Garrett JR (1986) Identification of water quality differences Nevada through index application. J Environ Qual 15(3):265-272

Moore BC, Lafer JE, Funk WH (1994) Influence of aquatic macrophytes on phosphorus and sediment porewater chemistry in a freshwater wetland. Aquat Bot 49:137-148

Naiman RJ, Decamps H, Pollock M (1993) The role of riparian corridors in maintaining regional biodiversity. Ecol Appl 3(2):209-212

Nair NC, Henry AN (1983) Flora of Tamil Nadu, India, vol 1. Series I: analysis. Botanical Survey of India, Coimbatore

Neelam R, Nair V (1997) Distribution and abundance of copepods in the pollution gradient zones of Bombay harbour-ThanecreekBasin creek, West coast of India. Indian J Mar Sci 26:20-25

Norlin JI, Bayley SE, Ross LCM (2005) Submerged macrophytes, zooplankton and the predominance of low-over high-chlorophyll states in western boreal, shallow-water wetlands. Freshw Biol 50:868-881

Palit D, Mukherjee A (2012) Studies on the water quality and macrophytes composition in wetlands of Bankura district, West Bengal India. Indian J Plant Sci 1:221-228
Penfound WT, Earle TT (1948) The biology of the water hyacinth. Ecol Monogr 18:449-472

Rakocy JE, Allison R (1981) Evaluation of a closed re circulating system for the culture of Tilapia and aquatic macrophytes. In: Allen LJ, Kinney EC (eds) Proceedings of bio-engineering symposium for fish culture. American Fisheries Society, Publ. No. 1, Washington, pp 296-307

Robach F, Thiebaud G, Tremolieres M, Muller S (1996) A reference system for continental running waters: plant communities as bioindicators of increasing eutrophication in alkaline and acidic water in northeast France. Hydrobiologia 340:67-76

Ruttner F (1953) Fundamentals of limnology. University of Toronto Press, Toronto

Saini DC, Singh SK, Raj K (2010) Biodiversity of aquatic and semiaquatic plants of Uttar Pradesh (with special reference to eastern Uttar Pradesh). Uttar Pradesh State Biodiversity Board, Lucknow

Secmen O, Leblebici E (1996) The vegetation cover of Marmara region wetlands. Turk J Bot 20:171-187

Singh RP, Mathur P (2005) Investigation of physico-chemical characteristics of freshwater reservoir of Ajmer city Rajasthan. Indian J Environ Sci 19:179-186

Sondergaard M, Johansson LS, Lauridsen TL, Jorgensen TB, Liboriussen L, Jeppesen E (2010) Submerged macrophytes as indicators of the ecological quality of lakes. Freshw Biol 55:893-908

Sooknah RD, Wilkie AC (2004) Nutrient removal by floating aquatic macrophytes cultured in anaerobically flushed dairy manure wastewater. Ecol Eng 22:27-42

Sridhar R, Thangaradjou T, Senthil Kumar S (2006) Water quality and phytoplankton characteristics in the Palk Bay, southeast coast of India. J Environ Biol 27:561-566

Tank SK, Chippa RC (2013) Analysis of water quality of Halena block in Bharatpur area. Int J Sci Res Publ 3(3):1-6

Thakor FJ, Bhol DK, Pandya SN, Chauhan NB (2011) Water quality index (W.Q.I.) of Periyej lake district, Kheda-Gujarat. Curr World Environ 6(2):225-231

Tripathi BD, Shukla SC (1991) Biological treatment of wastewater by selected aquatic plants. Environ Pollut 69(1):69-78

Verma P, Chandawat D, Gupta U, Solanki H (2012) Water quality analysis of an organically polluted lake by investigating different physical and chemical parameters. Int $\mathbf{J}$ Res Chem Environ 2(1):105-111

Wetzel RG (1966) Variations in productivity of Goose and hypereutrophic Sylvan lakes, Indiana. Invest Indiana Lakes Streams 7:147-184

Williams M (1990) Wetlands: a threatened landscape. B. Blackwell, Oxford

Publisher's Note Springer Nature remains neutral with regard to jurisdictional claims in published maps and institutional affiliations. 